Review

\title{
Drosophila as a lipotoxicity model organism - more than a promise?
}

\author{
Ronald P. Kühnlein * \\ Max Planck Institute for Biophysical Chemistry, Department of Molecular Developmental Biology, Am Fassberg 11, 37077 Göttingen, Germany
}

\section{A R T I C L E I N F O}

\section{Article history:}

Received 8 July 2009

Received in revised form 4 September 2009

Accepted 13 September 2009

Available online 23 September 2009

\section{Keywords:}

Drosophila

Lipotoxicity

Model organism

Energy homeostasis

Lipometabolism

\begin{abstract}
A B S T R A C T
Looking back over the century long research career of the fruit fly, Drosophila melanogaster has frequently been in the scientific spotlight with respect to fundamental discoveries in biology. The last decade witnessed the increasing importance of the fly as a human disease model but studies on energy homeostasis and lipometabolism remain in their infancy. This perspective, addressing readers largely unfamiliar with the Drosophila model system, aims to highlight the starting points for which the fly could be employed to gain a deeper understanding of lipotoxicity and possibly contribute to strategies for the identification of novel drug targets relevant to type 2 diabetes mellitus and the metabolic syndrome.
\end{abstract}

(c) 2009 Elsevier B.V. All rights reserved.

\section{Drosophila as a model system for human diseases}

The fruit fly has an excellent reputation as a cost-effective model organism with a comprehensive and versatile technical methodologies repertoire for gene identification and gene function analysis [1]. A short life cycle permits around 30 fly generations a year and allows rapid genetic screens, combinatorial genetics and genetic background adjustment - techniques indispensable for the analysis of complex metabolic phenotypes. Extensive fly stock collections providing access to thousands of mutant and transgenic fly strains complement Flybase, the excellent Drosophila research database [2] (www. flybase.org). These resources ease forward and reverse genetic screens [3], which are still at the heart of fly research. Genome-wide gene expression profiles [4] (www.flyatlas.org), genome-wide RNAi technology in Drosophila cell lines and primary cells $[5,6]$ as well as in vivo [7] and conditional knockout technology [8] are more recent additions to the Drosophila researchers toolbox. The use of genetic mosaic animals is of outstanding value for the analysis of complex metabolic phenotypes arising from crosstalk between different tissues/organs. In this regard the fly system offers unparalleled spatio-temporal resolution either through the combination of RNAimediated gene knockdown with switchable in vivo expression systems [9] or by recombination-based genetic mosaic analysis $[10,11]$. Beyond the talents of the Drosophila system for gene discovery and gene functional analysis, the fly has proven useful in neuropharmacological research [12] and chemical genetic screens have also been successfully performed, for example on a fly model for the human fragileXsyndrome [13].

\footnotetext{
* Corresponding author. Tel.: +49 0551 2011045; fax: +49 05512011755

E-mail address: rkuehnl@gwdg.de.
}

Modelling human physiological and pathophysiological conditions in the fly (conceptually reviewed in refs. $[14,15]$ ) has been spurred by the surprising finding that around $70 \%$ of human disease genes have bona fide orthologues in the fly genome $[16,17]$ (superfly.ucsd.edu/ homophila). The Drosophila system is currently being used for basic and applied research on a broad spectrum of human pathologies including infectious diseases [18], cancer [19-23], seizure disorders [24], drug abuse [25,26] and neurodegenerative diseases [27-30], to name but a few.

Establishment of any fly model for a human disease is a two-step process. First, a fly model "patient" is created using reverse genetics, which involves either mutating the Drosophila orthologue of the human disease gene or "humanising" the fly via introduction of a transgene harbouring the desired human disease gene, which has no bona fide orthologue in the fly.

Second, the pathogenic process of all fly disease models then need careful analysis to assess the extent of the similarity between the human and the fly disease symptoms and progression; this can vary widely depending on the diseases under study and eventually determines the value of the model (as exemplified for neurodegenerative diseases in ref. [29]).

Detailed analysis of the human disease fly model is also pivotal in the selection of an informative phenotypic readout amenable to largescale genetic screens to identify direct or indirect interactors of the gene of interest. A primary genetic screen aims to identify novel mutations, which phenocopy the human disease model phenotype. Alternatively the model itself may be used as the basis of a screen to identify modifiers (enhancers and suppressors) of the model phenotype. For example, general performance such as climbing or flight performance assays have been extensively used to identify muscle- or neurodegeneration candidate genes. Even organismal 
lethal mutations can be analysed in genetic modifier screens which employ genetically engineered mosaic flies to score genetic interactions exclusively in organs dispensable for fly survival such as eyes or wings [3]. In summary, modelling and analysis of human physiological and pathophysiological processes in the fly follows a multistep decision strategy. Therefore the question of whether or not the fly promises answers in the context of mammalian lipotoxicity research cannot be addressed without thorough prior comparative analysis to disclose the extent of common evolutionary heritage of organismal lipo- and carbohydrate homeostasis control.

Novices to the fly literature are advised with a cautionary note. Important metabolic studies in the fly have employed Drosophila larvae, transient ontogenetic stages dedicated to continuous feeding and growth. During the ensuing metamorphosis into the adult, the larval body plan is completely remodelled largely on the basis of proliferating and differentiating embryonic cell lineages, which replace many organs including metabolically important tissues such as the fat body. Accordingly, insights gained from larval metabolism studies need confirmation in the adult fly. An adult fly exhibits an intermittently feeding mode during its life, making this stage particularly suitable for research on progressive degenerative diseases such as lipotoxicity.

\section{Mammalian lipotoxicity at a glance}

According to the prevailing lipocentric view of the metabolic syndrome, lipotoxicity in peripheral tissues is the driving force behind the pathogenesis of insulin resistance and type 2 diabetes mellitus (T2DM). Therefore, obesity is regarded as the major risk factor for metabolic syndrome pathophysiology as high systemic levels of fatty acids (FAs) saturate the storage capacity of the adipose tissue resulting in "spill over." Such spill over results in triacylglyceride (TAG) accumulation in non-adipose tissues such as liver, heart, skeletal muscle and pancreatic islets. Ectopic neutral fat deposition in these tissues is exaggerated by excessive glucose-based lipogenesis in hyperglycaemia. Collectively, overstorage of lipids in non-adipose tissues drives FAs into non-oxidative, biosynthetic pathways causing accumulation of deleterious lipid metabolites such as ceramides. Subsequently, the plethora of reactive lipid metabolites trigger cellular dysfunctions, summarised as lipotoxicity effects, which eventually lead to skeletal muscle insulin resistance, liver steatosis, cardiomyopathies, pancreatic $\beta$-cell failure and ultimately to lipoapoptosis of the affected cells.

A potent lipoprotective strategy in mammals orchestrated by adipokines is coordinated FA utilisation and storage to cope with over-nutrition. In peripheral non-adipose tissues FA oxidation is stimulated and glucose-based lipogenesis is suppressed, whereas adipose tissue hyperplasia and hypertrophy "detoxifies" FAs through storage of surplus TAG. For example, leptin down-regulates the prolipogenic transcription factor sterol regulatory element-binding protein-1c (SREBP-1c) in the liver. Since SREBP-1c controls the expression of a number of lipogenic enzymes, including acetyl-CoA carboxylase (ACC), down-regulation of SREBP-1c causes a decrease in malonyl-CoA which in turn acts as an inhibitor of carnitine palmitoyltransferase-1 (CPT-1)-mediated $\beta$-oxidation of FAs. Additionally, $\beta$-oxidation can be stimulated by inhibitory phosphorylation of ACC by AMP-dependent protein kinase (AMPK), which monitors the energy status of the cells. Simultaneously hyperleptinaemia stimulates peroxisomal proliferator activated receptor- $\alpha$ (PPAR- $\alpha$ ), which up-regulates enzymes of mitochondrial and peroxisomal FA oxidation as well as peroxisomal proliferator activated receptor- $\gamma$ coactivator $1 \alpha$ (PGC-1 $\alpha$ ), which controls mitochondrial biogenesis.

Does this delicate balance between pro-lipotoxic mechanisms and protective strategies maintaining lipometabolism homeostasis operate in the fly? To obtain an answer to this question readers are invited in the following paragraphs to look at man and mouse from the perspective that they represent model organisms for the fly and thereby to match the wealth of mammalian lipotoxicity information with the limited knowledge derived from the corresponding current research in Drosophila. By carrying out such an analysis, rather than a comprehensive overview on a research field in statu nascendi, it is hoped that decision guidelines of what to ask first in the attempt to employ Drosophila as a lipotoxicity model organism can be provided.

\section{Of fly and man: Comparative anatomy of organismal energy homeostasis}

Superficial inspection of the fly's anatomy with regard to mammalian lipotoxicity target organs is not encouraging, as Drosophila lacks a pancreas and liver. However, pancreatic $\alpha$-cell functions are fulfilled by so-called corpora cardiaca (CC) cells [31] localised in a neuroendocrine organ named the ring gland, and insulin-producing cells (IPCs) analogous to the pancreatic $\beta$-cells are localised in the central brain [32]. Interestingly, a recent cell lineage analysis revealed that the molecular signature of embryonic CC cell and IPC progenitors in the fly shares similarities with progenitors of the mammalian brain-endocrine axis [33]. Though speculative at the moment, this finding opens the possibility that the brain endocrine regulatory modules are used for specification of the pancreatic islet cells, which would make them more related to their functionally analogous fly counterparts than otherwise anticipated given their clearly different ontogenetic origin and anatomic location.

The metabolic and storage functions of the mammalian liver are shared by two organ systems in the fly. While glycogen storage largely resides in the insect fat body, groups of cells located in the larval cuticle called oenocytes have been demonstrated to fulfil liver-like functions in lipometabolism [34]. Oenocytes express a variety of lipid metabolising genes and accumulate neutral lipids upon starvation as observed in mammalian hepatic steatosis.

Two other lipotoxicity target cell types appear more readily comparable between flies and mammals: cardiomyocytes and skeletal muscle cells. Cardiomyocytes build the so-called dorsal vessel, the linear heart tube of the fly, which pumps the insect blood through an open circulatory system. Continuously improved analytical systems have been developed to monitor heart performance of embryonic, larval and adult fly hearts [35-39]. An automatic screening device which can acquire adult fly heart rate and rhythm has been devised thereby enabling medium scale genetic screens [40]. With the availability of such multiparameter analytical devices, progressive, and particularly age-related cardiac dysfunction, has been studied (reviewed in refs. [41-43]). Moreover, diverse human cardiac diseases have been modelled in the fly such as the GATA4 haplo-insufficiency [44], arrhythmia [45] or dilated cardiomyopathy due to loss of dystrophin [46]. Notably, a cell-autonomous down-regulation of insulin signalling in the heart [47] or a systemic decrease in target of rapamycin (TOR) signalling [48] has been shown to prevent an age-dependent increase in fly heart failure. Thus, this rich tradition in studying degenerative cardiomyopathies combined with sophisticated technology to track cardiac performance clearly sets the stage to analyse potential lipotoxicity effects on Drosophila cardiomyocytes.

Drosophila myocytes serve all aspects the fly's terrestrial and airborne locomotion with an insects indirect flight muscles being among the metabolically most active tissues in the animal kingdom. Muscle development in flies and vertebrates is strikingly similar [49] and skeletal muscle myopathy Drosophila models have been established [50] including dystrophin/dystroglycan [51,52] and sarcoglycan mutants [53], a model for hypercontraction-induced myopathy [54] and a Barth syndrome model, which shows muscle weakness due to mitochondrial myopathy caused by cardiolipin deficiency [55]. However, the conditions and extent of intramyocellular lipid storage has not been systematically addressed in the fly. 
A nodal point of energy homeostasis regulation in the fly is the fat body, named for its most prominent function in fat storage and serving as metabolic sink for dietary lipid similarly to mammalian adipose tissue. However as mentioned above, the fat body also governs substantial glycogen stores and has additional essential functions e.g. in the innate immunity response of the fly. Little is known about potential functions of the fat body as an endocrine organ in energy homeostasis control. In particular, there is no fly orthologue of the leptin gene. Nevertheless there is a requirement for a leptin-like humoral signal in the fly to communicate the energetic status of the fat body to the brain and other peripheral tissues. Identification of such a proposed fly leptin-analogue would also indicate whether an anti-steatosis function of fat storage tissue by remote-control lipogenesis repression and $\beta$-oxidation enhancement in non-adipose cells is an ancient evolutionary trait.

Organ plasticity is a characteristic of mammalian adipose tissue. In human individuals adipocyte cell number is determined at the preadult stage and kept constant by a tightly controlled equilibrium between adipocyte cell death and differentiation [56]. Adipose tissue responds to lasting positive energy balance by hypertrophy, although hyperplasia might also play a role in pathological conditions [57]. Similarly, the fly fat body consists of a defined number of cells during larval ontogenesis [58] and shows hypertrophy during larval and adult developmental stages; the occurrence of fat body hyperplasia is still under study. Similarly to mammalian adipose tissue, the adult fly fat body consists of different anatomically delimitable fat depots such as the deep and peripheral fat, and the head and abdominal fat body [59]. Little is known about functional diversification within the fly adult fat body, however, differences between insulin signalling in the head vs. abdominal fat body have been reported [60].

Taking these observations together, namely the pancreatic isletlike IPC and CC cells of the brain and ring gland, respectively, and the hepatocyte-like oenocytes as well as the cardiomyocytes and skeletal muscle myocytes, Drosophila clearly has various cell types functionally analogous to mammalian lipotoxicity target tissues.

\section{A tiny patient: physiology of lipo- and carbohydrate metabolism in the fly}

The wealth of knowledge about all aspects of Drosophila biology makes the fly one of the best-studied animals but the information on its energy metabolism is relatively scarce. However, monitoring physiological parameters and pathophysiological dysfunctions of a "patient" 2-3 $\mathrm{mm}$ in size with a total blood volume of less than a microliter and meal sizes in the nanoliter range is certainly a challenge. Only recently developed sensitive methodology allows comprehensive energy flux analysis in the fly together with food intake $[61,62]$, metabolic rate measurements $[63,64]$ and defecation [65] on a per animal basis. Although varying food quality composition has been studied in Drosophila in the context of dietary-restricted lifespan extension [66,67], precise measurement of food intake spurs nutrigenomics research [68] and has proved the occurrence of dietinduced obesity [69] and a circadian feeding rhythm in the fly [70].

Several recent reviews are dedicated to the emerging role of Drosophila in energy homeostasis research [71-74]. Two antagonistic and interacting signalling pathways control energy metabolism in the fly: the insulin pathway and the adipokinetic hormone $(\mathrm{AKH})$ pathway. These two pathways govern the traffic and interconversion of the two central energy currencies, carbohydrates (transport forms: trehalose, glucose; storage form: glycogen) and fats (transport form: diacylglycerol; storage form: triacylglycerol). The major source for Drosophila insulin-like peptides (DILPs) are the pancreatic islet $\beta$ cell-like IPCs in the central brain. Ablation of IPCs causes increased blood sugar levels in Drosophila larvae, which can be corrected by expressing insulin-like DILP2 [32]. The glucagon-like AKH is secreted by corpora cardiaca (CC) cells, which show striking similarity to islet $\alpha$-cells in sensing glucose concentrations and controlling hormone secretion via ATP-sensitive potassium channels [31]. Ablation of AKHpositive CC cells decreases the blood sugar level in larvae, which can be ameliorated with systemic AKH expression $[31,75,76]$. Conversely, inactivation of the AKH receptor has been reported to increase glycogen [77] as well as fat storage [77,78] in flies. Insulin signalling is also intimately linked to lipometabolism in flies as exemplified by the identification of the LIP4 acid lipase as a transcriptional forkhead box, group O (FOXO) target gene [79]. Moreover, lipid storage increase by insulin pathway activation in non-adipose cells has been demonstrated in oocyte nurse cells [80].

Basic insect lipometabolism (reviewed in ref. [81]) closely resembles the corresponding mammalian pathways including central regulatory switches such as SREBP in lipogenesis [82,83], hepatocyte nuclear factor 4 (HNF4) in lipocatabolism [84] or the ACC phosphorylation by AMPK in response to ATP depletion [85]. The central components of the TAG storage homeostasis are also evolutionarily conserved as exemplified by the lipid understorage of midway mutants lacking fly diacylglycerol O-acyltransferase 1 (DGAT1) (ref. [86] and Kühnlein unpublished) and by the obesity of brummer mutant flies [87] lacking the Drosophila orthologue of mammalian adipose triglyceride lipase ATGL/PNPLA2 (reviewed in ref. [88]). Loss of ATGL function causes systemic TAG accumulation in mice [89,90] and neutral lipid storage disease in man [91]. Triglyceride storage is a prime example of how a phenotypic readout can be used by various experimental strategies in Drosophila to identify candidate genes relevant to human disease. Genome-wide RNAi knockdown screens in Drosophila cell culture identified the retrograde coat protein complex I (COPI) vesicle transport system as a critical determinant for cellular lipid storage [92,93]. At the whole organismal level, quantitative trait loci (QTL) mapping of recombinant inbred lines for body lipid content is being employed to identify candidate genes [94,95]. Finally, characterisation of the molecular defect in the spontaneous fly mutant adipose $[96,97]$ let to the identification of the genes mammalian orthologue WDTC1 as a novel obesity gene in mouse [98] and man [99].

In addition to lipid storage disorders, neurodegenerative diseases caused by lipometabolism defects such as the Niemann-Pick disease type C $[100,101]$ are being studied in the fly. This emphasises once more the relevance of evolutionary conservation between flies and man with respect to metabolism (for an extended view on evolutionarily conserved genes affecting lipometabolism see Table 1).

\section{Lipotoxicity effector genes and pathways in Drosophila}

Reactive oxygen species (ROS) are regarded as major lipotoxicity mediators of peripheral insulin resistance. ROS are unwanted byproducts of normal mitochondrial function and cause peroxidation of lipid metabolism intermediates, which accumulate and cause oxidative damage to proteins and nucleic acids resulting in, for example, mitochondrial dysfunction and apoptosis. A lipid peroxidation assay quantifying 4-hydroxy-2-nonenal (HNE)-oxidised proteins has been adapted for Drosophila [102]. This study identified the fat body, thoracic muscles and neurons as major lipid peroxidation target tissues in response to induced oxidative stress. Moreover, the authors showed that lipid peroxidation damage accumulates in aging flies and can be delayed by calorie restriction. A similar study showed progressive apoptosis in ageing muscles and fat body cells [103]. Consistent with this, peroxiredoxin 5 protects oenocytes and muscles from apoptosis in adult flies [104], and superoxide dismutase 2 (SOD2) knockdown in the adult fly musculature induces mitochondrial dysfunction and myocyte degeneration [105].

Taken together these reports provide ample evidence of oxidative damage sensitivity of putative lipotoxicity target tissues in the fly.

The role of mitochondrial uncoupling proteins (UCPs) in mammalian lipotoxicity is still under discussion. For example, UCP1 
Table 1

Drosophila genes affecting lipometabolism and their human orthologues.

\begin{tabular}{|c|c|c|}
\hline Drosophila gene (abbreviation) & Human orthologue & Reference \\
\hline \multicolumn{3}{|l|}{ Lipid droplets } \\
\hline $\begin{array}{l}\text { [Perilipin1/Lipid storage droplet-1], } \\
\text { Perilipin2/Lipid storage droplet-2 } \\
\text { ([plin1/Lsd-1], plin2/Lsd-2) }\end{array}$ & $\begin{array}{l}\text { PERILIPINs } \\
\text { (PLIN1-5) }\end{array}$ & {$[145-147]$} \\
\hline ADP ribosylation factor $79 F$ ( $A r f 79 F)$ & ARF1 & {$[92,93]$} \\
\hline gartenzwerg (garz) & GBF1 & [93] \\
\hline COPI subunits & COPI subunits & {$[92,93]$} \\
\hline CG7580 & UQCRQ & [92] \\
\hline brahma (brm) & SMARCA4 & [92] \\
\hline \multicolumn{3}{|l|}{ Lipoanabolism } \\
\hline midway (mdy) & DGAT1 & {$[86,92,93]$} \\
\hline $\begin{array}{l}\text { dSREBP/ Helix loop helix } \\
\text { protein } 106 \text { (HLH106) }\end{array}$ & SREBPS & {$[82,93]$} \\
\hline SCAP & SCAP & [93] \\
\hline desat1 & $S C D$ & {$[119,150]$} \\
\hline \multicolumn{3}{|l|}{ Lipocatabolism } \\
\hline brummer (bmm) & PNPLA2/LAL & {$[87,92]$} \\
\hline [Lipase 4 (Lip4)] & $L I P A / L A L$ & [79] \\
\hline swiss cheese (sws) & PNPLA6/NTE & {$[151]$} \\
\hline Enigma (Egm) & $\begin{array}{l}\text { acyl-CoA } \\
\text { dehydrogenases }\end{array}$ & [152] \\
\hline Hepatocyte nuclear factor 4 (Hnf4) & $H N F 4 A, G$ & [84] \\
\hline \multicolumn{3}{|l|}{ Cholesterol metabolism } \\
\hline Niemann-Pick type C-1a (Npc1a) & NPC1 & {$[101,153]$} \\
\hline Niemann-Pick type $C-1 b(N p c 1 b)$ & NPC1L1 & {$[154]$} \\
\hline \multicolumn{3}{|l|}{ Phospholipid metabolism } \\
\hline Tafazzin (Taz) & TAZ & [55] \\
\hline $\begin{array}{l}\text { CTP:phosphocholine cytidylyltransferase } \\
1 \text { and } 2 \text { (Cct1, Cct2) }\end{array}$ & PCYT1 & [93] \\
\hline \multicolumn{3}{|l|}{ Sphingolipid metabolism } \\
\hline Sphingosine-1-phosphate lyase (Sply) & SPGL1 & {$[129,132]$} \\
\hline GlcT-1 & UGCG & {$[130]$} \\
\hline \multicolumn{3}{|l|}{ Energy homeostasis signalling } \\
\hline Insulin-like peptide 2,3,5 (Ilp2,3,5) & INS and IGF isoforms & [32] \\
\hline Insulin-like receptor (InR) & INSR & [155] \\
\hline chico & IRS1-4 & {$[156]$} \\
\hline Akt1 & AKT isoforms & {$[80]$} \\
\hline Lnk & SH2B3 & [157] \\
\hline widerborst (wbd) & PPP2R5E & [158] \\
\hline forkhead box sub-group $O$ (foxo) & FOXO isoforms & {$[48,60]$} \\
\hline Adipokinetic hormone (Akh) & GCG (Glucagon)* & {$[31,75,76,78]$} \\
\hline $\begin{array}{l}\text { Adipokinetic hormone } \\
\text { receptor/Gonadotropin-releasing } \\
\text { hormone receptor (Akhr/GRHR) }\end{array}$ & & {$[77,78]$} \\
\hline Target of rapamycin (Tor) & MTOR & {$[48,159]$} \\
\hline Thor/4E-BP & EIF4EBP & {$[160]$} \\
\hline melted (melt) & VEPH1 & [159] \\
\hline$m i R-278$ & & [161] \\
\hline expanded (ex) & FERM domain proteins & {$[161]$} \\
\hline Lk6 & MKNK1, 2 & {$[162]$} \\
\hline Neural Lazarillo (NLaz) & APOD & [163] \\
\hline \multicolumn{3}{|l|}{ Others } \\
\hline adipose (adp) & WDTC1 & [97] \\
\hline bride of sevenless (boss) & GPRC5B & {$[164]$} \\
\hline Bmcp/dUCP5 & UCP5/SCL25A14 & {$[165]$} \\
\hline bubblegum (bgm) & ACSBG1 & {$[166,167]$} \\
\hline $\begin{array}{l}\text { lethal (2) 44DEa (l(2)44DEa/ dAcsl) } \\
\text { miR-14 }\end{array}$ & ACSL3, 4 & $\begin{array}{l}{[93,168]} \\
{[169]}\end{array}$ \\
\hline Activating transcription factor-2 (Atf-2) & NPDC-1 & {$[170]$} \\
\hline Cytochrome P450-4g1 (Cyp4g1) & lipid $\varpi$-hydrolases & {$[34]$} \\
\hline Invadolysin & $L M L N$ & [171] \\
\hline cubitus interruptus (ci) & $G L I$ isoforms & {$[172]$} \\
\hline patched (ptc) & PTCH1, 2 & {$[173,174]$} \\
\hline
\end{tabular}

Brackets: Lipometabolism function in Drosophila predicted.

a Nomenclature follows [141]. Note that numbering of the Drosophila PLINs does not infer orthology to the correspondingly numbered mammalian PLINs.

* Functional analogue. overexpression in skeletal muscle improves glucose metabolism but causes mitochondrial myopathy and intramyocellar TAG accumulation [106]. Muscle UCP3 protein is upregulated upon high-fat feeding or in a rat cachexia model characterised by increased oxidative stress and plasma free FA ([107]; also reviewed in ref. [108]) and is believed to act as a lipoprotective in mitochondria by exporting unoxidised FAs from the mitochondrial matrix [109]. On the other hand, a lack of UCP2 has been found to protect pancreatic $\beta$-cells from FA-induced lipotoxic effects such as TAG accumulation and loss of glucose sensitivity. Conversely, $\beta$-cells overexpressing UCP2 suffer from reduced glucose-simulated insulin secretion [110]. Flies lack orthologues of human UCP2 and UCP3 [111] but conservation of mitochondrial uncoupling has been demonstrated for the Drosophila UCP5 homologue [112]. Consistent with this, human UCP2 (hUCP2) expression in fly neurons reduces ROS production and oxidative damage [113]. Additionally, human UCP3 (hUCP3) is capable of mitochondrial uncoupling in flies and its targeted in vivo expression in $\beta$-cell-like IPCs increases DILP abundance [114] by an unknown post-transcriptional mechanism. These data suggest that endogenous UCP function might be relevant for insulin-secreting cells and as such an attractive means to decipher the function of uncoupling proteins in lipotoxicity.

Steaoryl-CoA desaturase- 1 (SCD-1) is the rate-limiting step in the production of monounsaturated fatty acids from saturated precursors and has been shown to protect various mammalian cell types from lipotoxicity. For example, SCD-1 protects primary human endothelial cells against palmitate-induced lipotoxicity and apoptosis [115] and prevents steatohepatitis in mice [116]. Conversely, inhibition of SCD-1 by conjugated trans-10, cis- 12 linoleic acid augments saturated fatty acid-induced ER stress and apoptosis in H4IIE liver cells [117]. Similar to SCD-1 knockout mice [118], flies mutant for the Drosophila SCD-1 orthologue desat1, have a dramatically reduced lipid content [119]. However, a possible involvement of desat1 in ameliorating lipotoxicity has not yet been addressed.

Ceramide is a potent apoptosis inducer [120] and has been implicated in lipoapoptosis of different target tissues susceptible to lipotoxicity. For example ceramide is involved in lipotoxic cardiomyopathy [121-123] and FA-induced pancreatic $\beta$-cell apoptosis $[124,125]$. Moreover, ceramide can trigger nitric oxide (NO) mediated apoptosis through NF- $\kappa \mathrm{B}-$ dependent expression of inducible NO synthase (iNOS) in $\beta$-cells [126]. Finally, ceramide might contribute to insulin resistance by inhibiting glucokinase transcription in hepatocytes [127].

In Drosophila the key sphingolipid metabolism enzymes, including those of the ceramide biosynthetic pathway, are conserved $[128,129]$. Studies in the fly have supported the role of sphingolipid/ ceramide as apoptosis mediators. Knockdown of glucosylceramide synthase increases ceramide and apoptosis levels in flies [130]. Similarly Drosophila sphingosine-1-phosphate lyase (Sply) gene mutants accumulate sphingolipid intermediates and show increased apoptosis in embryos and gonads, as well as flight muscle abnormalities [131,132]. Conversely, targeted overexpression of ceramidase suppresses different photoreceptor degeneration pathways in flies, including apoptotic cell death [133]. In summary, the current data suggest that it would be useful to study the lipoapoptotic pathways involving sphingolipids/ceramide further in the fly although their relevance for fly tissues involved in energy metabolism remains to be demonstrated.

Endoplasmatic reticulum (ER) stress is an increasingly acknowledged contributor to lipoapoptosis. ER stress has been implicated in FA-induced apoptosis of various susceptible cell types such as pancreatic $\beta$-cells [134], H9c2 cardiomyoblasts [135] and H4IIE liver cells [117]. Moreover, ER stress and the counteracting unfolded protein response (UPR) have been implicated in intestinal cell lipotoxicity [136]. In Drosophila, ER stress and UPR protection is being studied in the context of retinal degeneration [137,138; 
reviewed in ref. 139] but once again an important lipotoxicity effector pathway still needs to be studied in relevant tissues in this system.

Triglyceride accumulation in non-adipose tissue in response to excess FA is regarded not only as a diagnostic marker for lipotoxicity progression but also as lipoprotective mechanism in pre-lipotoxic stages. A recent study reports the expression of Perilipin in islet cells [140]. Perilipin is the founding member of the PERILIPIN protein family [141] consisting of evolutionarily conserved lipid dropletassociated proteins with central functions in fat storage and mobilisation (reviewed in refs. [142-144]). Interestingly, overexpression of PERILIPIN (PLIN1) protects INS- 1 rat $\beta$-cells against palmitatetriggered lipotoxicity [140]. This suggests that PERILIPIN-dependent TAG storage in non-adipose tissue might represent a more general protective strategy against lipotoxicity. Notably, both of the Drosophila PERILIPINs PLIN1/LSD-1 and PLIN2/LSD-2 control body fat storage in the fly ([145-147]; and Kühnlein, unpublished) and PLIN2/ LSD-2 has also been demonstrated to govern cellular TAG stores outside the fat body, i.e. in wing imaginal disc cells and oocyte nurse cells $[80,148]$. However, the expression and function of PERILIPIN proteins in potentially lipotoxicity-relevant fly tissues remains to be addressed.

\section{Perspectives of lipotoxicity research in the fly}

As detailed above, the key factors and mechanisms involved in mammalian lipotoxicity progression are conserved in those tissues/ organs of the fly with functional analogy to lipotoxicity target tissues in mammalian model systems and man. Moreover, current technology in Drosophila allows monitoring of critical lipotoxicity-relevant physiological and pathophysiological parameters. Yet, the major phenotype of lipotoxicity, namely excessive lipid storage in metabolically relevant non-adipose tissues, has not been systematically addressed in the fly. Nor have Drosophila studies covered the potentially adverse chronic effects of elevated circulating blood sugar and lipid levels in response to either over-nutrition or genetic manipulations. Only when such studies are conducted can Drosophila promise to become an informative and useful model system in which lipotoxicity research questions can be addressed.

The fly is a particularly attractive system to study two of the known mammalian lipotoxicity target tissues. On one hand, the phenotypic consequences of the functional impairment of $\beta$-cell-like IPCs are being studied in the context of life span extension. And on the other, cardiomyocytes with their outstanding technical accessibility provide the means to detect degenerative processes in vivo. In addition to in vivo studies in the organism itself, the steadily growing number of stable Drosophila cell lines (available from the Drosophila Genomics Resource Center (DGRC); dgrc.cgb.indiana.edu), as well as differentiated primary culture cells such as myocytes [149], promise new experimental approaches to lipotoxicity research in the fly in the near future.

\section{Acknowledgements}

I apologise for the omission of any relevant publications that have not been included either due to the very specific focus of this review or to space constraints. The author is grateful to Susan Smith for careful reading of the manuscript. This work was supported by the Max Planck Society.

\section{References}

[1] K.A. Matthews, T.C. Kaufman, W. Gelbart, Nat. Rev. Genet. 6 (2005) 179-193.

[2] S. Tweedie, M. Ashburner, K. Falls, P. Leyland, P. McQuilton, S. Marygold, G. Millburn, D. Osumi-Sutherland, A. Schroeder, R. Seal, H. Zhang, F. Consortium, Nucleic Acids Res. 37 (2009) D555-D559.

[3] D. St Johnston, Nat. Rev. Genet. 3 (2002) 176-188.

[4] V. Chintapalli, J. Wang, J. Dow, Nat. Genet. 39 (2007) 715-720.
[5] N. Perrimon, B. Mathey-Prevot, Genetics 175 (2007) 7-16.

[6] N. Ramadan, I. Flockhart, M. Booker, N. Perrimon, B. Mathey-Prevot, Nat. Protoc. 2 (2007) 2245-2264

[7] G. Dietzl, D. Chen, F. Schnorrer, K.C. Su, Y. Barinova, M. Fellner, B. Gasser, K. Kinsey, S. Oppel, S. Scheiblauer, A. Couto, V. Marra, K. Keleman, B. Dickson, Nature 448 (2007) 151-156.

[8] C.M. Choi, S. Vilain, M. Langen, S. Van Kelst, N. De Geest, J. Yan, P. Verstreken, B.A. Hassan, Science 324 (2009) 54

[9] S.E. McGuire, G. Roman, R.L. Davis, Trends Genet. 20 (2004) 384-391.

10] J.S. Wu, L. Luo, Nat. Protoc. 1 (2006) 2583-2589.

[11] T. Xu, G.M. Rubin, Development 117 (1993) 1223-1237.

[12] H. Manev, N. Dimitrijevic, S. Dzitoyeva, Trends Pharmacol. Sci. 24 (2003) 41-43.

[13] S. Chang, S.M. Bray, Z. Li, D.C. Zarnescu, C. He, P. Jin, S.T. Warren, Nat. Chem. Biol. 4 (2008) 256-263.

[14] A. Bernards, I.K. Hariharan, Curr. Opin. Genet. Dev. 11 (2001) 274-278.

[15] C.J. O'Kane, Semin. Cell Dev. Biol. 14 (2003) 3-10.

[16] S. Chien, L.T. Reiter, E. Bier, M. Gribskov, Nucleic Acids Res. 30 (2002) 149-151.

[17] L.T. Reiter, L. Potocki, S. Chien, M. Gribskov, E. Bier, Genome Res. 11 (2001) 1114-1125.

[18] M.S. Dionne, D.S. Schneider, Dis. Model. Mech. 1 (2008) 43-49.

[19] C.M. Browne, G.R. Hime, P. Koopman, K.L. Loveland, Cell Tissue Res. 322 (2005) 5-19.

[20] P.O. Humbert, N.A. Grzeschik, A.M. Brumby, R. Galea, I. Elsum, H.E. Richardson, Oncogene 27 (2008) 6888-6907.

[21] C.J. Potter, G.S. Turenchalk, T. Xu, Trends Genet. 16 (2000) 33-39.

[22] J.E. Sutcliffe, M. Korenjak, A. Brehm, Eur. J. Cancer. 39 (2003) 1355-1362.

[23] M. Vidal, R.L. Cagan, Curr. Opin. Genet. Dev. 16 (2006) 10-16.

[24] S.C. Baraban, Curr. Opin. Neurol. 20 (2007) 164-168.

[25] H.J. Bellen, Cell 93 (1998) 909-912.

[26] M.E. Wolf, Curr. Biol. 9 (1999) R770-R772

27] H.Y. Chan, N.M. Bonini, Cell Death Differ. 7 (2000) 1075-1080.

[28] M.E. Fortini, N.M. Bonini, Trends Genet. 16 (2000) 161-167.

[29] A. Jeibmann, W. Paulus, Int. J. Mol. Sci. 10 (2009) 407-440.

[30] B. Lu, H. Vogel, Annu. Rev. Pathol. 4 (2009) 315-342.

[31] S.K. Kim, E.J. Rulifson, Nature 431 (2004) 316-320.

[32] E.J. Rulifson, S.K. Kim, R. Nusse, Science 296 (2002) 1118-1120.

[33] S. Wang, N. Tulina, D.L. Carlin, E.J. Rulifson, Proc. Natl. Acad. Sci. U. S. A. 104 (2007) 19873-19878.

[34] E. Gutierrez, D. Wiggins, B. Fielding, A. Gould, Nature 445 (2007) 275-280.

[35] A. Bradu, L. Ma, J.W. Bloor, A. Podoleanu, J. Biophoton. (2009).

[36] M.A. Choma, S.D. Izatt, R.J. Wessells, R. Bodmer, J.A. Izatt, Circulation 114 (2006) e35-e36.

[37] M. Fink, C. Callol-Massot, A. Chu, P. Ruiz-Lozano, J.C. Belmonte, W. Giles, R. Bodmer, K. Ocorr, Biotechniques 46 (2009) 101-113.

[38] R.J. Wessells and R. Bodmer, Biotechniques 37 (2004) 58-60, 62, 64 passim.

[39] M. Wu, T.N. Sato, PLoS One 3 (2008) e4045.

[40] J.D. Feala, J.H. Omens, G. Paternostro, A.D. McCulloch, Ann. N. Y. Acad. Sci. 1123 (2008) 169-177.

[41] E. Bier, R. Bodmer, Gene 342 (2004) 1-11.

[42] K. Ocorr, T. Akasaka, R. Bodmer, Mech. Ageing Dev. 128 (2007) 112-116.

[43] K. Ocorr, L. Perrin, H.Y. Lim, L. Qian, X. Wu, R. Bodmer, Trends Cardiovasc. Med. 17 (2007) 177-182.

[44] L. Oian, R. Bodmer, Hum. Mol. Genet. (2009).

[45] K. Ocorr, N.L. Reeves, R.J. Wessells, M. Fink, H.S. Chen, T. Akasaka, S. Yasuda, J.M. Metzger, W. Giles, J.W. Posakony, R. Bodmer, Proc. Natl. Acad. Sci. U. S. A. 104 (2007) 3943-3948.

[46] O. Taghli-Lamallem, T. Akasaka, G. Hogg, U. Nudel, D. Yaffe, J.S. Chamberlain, K. Ocorr, R. Bodmer, Aging Cell 7 (2008) 237-249.

[47] R.J. Wessells, E. Fitzgerald, J.R. Cypser, M. Tatar, R. Bodmer, Nat. Genet. 36 (2004) 1275-1281.

[48] N. Luong, C.R. Davies, R.J. Wessells, S.M. Graham, M.T. King, R.L. Veech, R. Bodmer, S.M. Oldham, Cell Metab. 4 (2006) 133-142.

[49] M. Taylor, Comparison of muscle development in Drosophila and vertebrates. 2006.

[50] J. Sparrow, S.M. Hughes, L. Segalat, Adv. Exp. Med. Biol. 642 (2008) 192-206.

[51] H.R. Shcherbata, A.S. Yatsenko, L. Patterson, V.D. Sood, U. Nudel, D. Yaffe, D. Baker, H. Ruohola-Baker, EMBO J. 26 (2007) 481-493.

[52] M.C. van der Plas, G.S. Pilgram, A.W. de Jong, M.R. Bansraj, L.G. Fradkin, J.N. Noordermeer, Mech. Dev. 124 (2007) 617-630.

[53] M.J. Allikian, G. Bhabha, P. Dospoy, A. Heydemann, P. Ryder, J.U. Earley, M.J. Wolf, H.A. Rockman, E.M. McNally, Hum. Mol. Genet. 16 (2007) 2933-2943.

[54] E.S. Montana, J.T. Littleton, J. Biol. Chem. 281 (2006) 8100-8109.

[55] Y. Xu, M. Condell, H. Plesken, I. Edelman-Novemsky, J. Ma, M. Ren, M. Schlame, Proc. Natl. Acad. Sci. U. S. A. 103 (2006) 11584-11588.

[56] K. Spalding, E. Arner, P. Westermark, S. Bernard, B. Buchholz, O. Bergmann, L. Blomqvist, J. Hoffstedt, E. Näslund, T. Britton, H. Concha, M. Hassan, M. Rydén, J. Frisén, P. Arner, Nature (2008) 5.

[57] K.J. Strissel, Z. Stancheva, H. Miyoshi, J.W. Perfield, J. DeFuria, Z. Jick, A. Greenberg, M.S. Obin, Diabetes 56 (2007) 2910-2918.

[58] T.M. Ritzki. in (Ashburner, A.W., T.R.F., ed.) The Genetics and Biology of Drosophila, Academic Press, New York 1978, pp. 561-601.

[59] A. Miller. in (Demerec, M., ed.) Biology of Drosophila, Cold Spring Harbour Laboratory Press 1950, pp. 420-534.

[60] D.S. Hwangbo, B. Gersham, M.P. Tu, M. Palmer, M. Tatar, Nature 429 (2004) 562-566. 
[61] W.W. Ja, G.B. Carvalho, E.M. Mak, N.N. de la Rosa, A.Y. Fang, J.C. Liong, T. Brummel, S. Benzer, Proc. Natl. Acad. Sci. U. S. A. 104 (2007) 8253-8256.

[62] R. Wong, M.D. Piper, B. Wertheim, L. Partridge, PLoS ONE 4 (2009) e6063.

[63] F.O. Lehmann, M.H. Dickinson, J. Staunton, J. Exp. Biol. 203 (Pt 10) (2000) 1613-1624.

[64] W.A. Van Voorhies, A.A. Khazaeli, J.W. Curtsinger, J. Insect Physiol. 50 (2004) $445-453$.

[65] R.S. Edgecomb, C.E. Harth, A.M. Schneiderman, J. Exp. Biol. 197 (1994) 215-235

[66] T.M. Bass, R.C. Grandison, R. Wong, P. Martinez, L. Partridge, M.D. Piper, J. Gerontol. A, Biol. Sci. Med. Sci. 62 (2007) 1071-1081.

[67] M.D. Piper, A. Bartke, Cell Metab. 8 (2008) 99-104.

[68] D.M. Ruden, M. De Luca, M.D. Garfinkel, K.L. Bynum, X. Lu, Annu. Rev. Nutr. 25 (2005) 499-522.

[69] D. Skorupa, A. Dervisefendic, J. Zwiener, S.D. Pletcher, Aging Cell 7 (2008) $478-490$.

[70] K. Xu, X. Zheng, A. Sehgal, Cell Metab. 8 (2008) 289-300.

[71] K.D. Baker, C.S. Thummel, Cell Metab. 6 (2007) 257-266.

[72] K.N. Bharucha, Pediatr. Res. 65 (2009) 132-137.

[73] P. Lasko, Clin. Genet. 62 (2002) 358-367.

[74] A. Schlegel, D. Stainier, PLoS Genet. 3 (2007) e199.

[75] G. Isabel, J.R. Martin, S. Chidami, J.A. Veenstra, P. Rosay, Am. J. Physiol. Regul. Integr. Comp. Physiol. 288 (2005) R531-538.

[76] G. Lee, J.H. Park, Genetics 167 (2004) 311-323.

[77] K.N. Bharucha, P. Tarr, S.L. Zipursky, J. Exp. Biol. 211 (2008) 3103-3110.

[78] S. Grönke, G. Müller, J. Hirsch, S. Fellert, A. Andreou, T. Haase, H. Jäckle, R. Kühnlein, PLoS Biol. 5 (2007) e137.

[79] T. Vihervaara, O. Puig, J. Mol. Biol. 376 (2008) 1215-1223.

[80] N. Vereshchagina, C. Wilson, Development 133 (2006) 4731-4735.

[81] L.E. Canavoso, Z.E. Jouni, K.J. Karnas, J.E. Pennington, M.A. Wells, Annu. Rev. Nutr. 21 (2001) 23-46.

[82] A. Kunte, K. Matthews, R.B. Rawson, Cell Metab. 3 (2006) 439-448.

[83] T. Porstmann, C.R. Santos, B. Griffiths, M. Cully, M. Wu, S.J. Leevers, J.R. Griffiths, Y.L. Chung, A. Schulze, Cell Metab. 8 (2008) 224-236.

[84] L. Palanker, J.M. Tennessen, G. Lam, C.S. Thummel, Cell Metab. 9 (2009) 228-239.

[85] D.G. Hardie, D.A. Pan, Biochem. Soc. Trans. 30 (2002) 1064-1070.

[86] M. Buszczak, X. Lu, W.A. Segraves, T.Y. Chang, L. Cooley, Genetics 160 (2002) 1511-1518.

[87] S. Grönke, A. Mildner, S. Fellert, N. Tennagels, S. Petry, G. Müller, H. Jäckle, R.P. Kühnlein, Cell Metab. 1 (2005) 323-330.

[88] M. Schweiger, A. Lass, R. Zimmermann, T.O. Eichmann, R. Zechner, Am. J. Physiol. Endocrinol. Metab. 297 (2009) E289-E296.

[89] G. Haemmerle, A. Lass, R. Zimmermann, G. Gorkiewicz, C. Meyer, J. Rozman, G. Heldmaier, R. Maier, C. Theussl, S. Eder, D. Kratky, E.F. Wagner, M. Klingenspor, G. Hoefler, R. Zechner, Science 312 (2006) 734-737.

[90] R. Zimmermann, J.G. Strauss, G. Haemmerle, G. Schoiswohl, R. Birner-Gruenberger, M. Riederer, A. Lass, G. Neuberger, F. Eisenhaber, A. Hermetter, R. Zechner, Science 306 (2004) 1383-1386.

[91] J. Fischer, C. Lefevre, E. Morava, J.M. Mussini, P. Laforet, A. Negre-Salvayre, M. Lathrop, R. Salvayre, Nat. Genet. 39 (2007) 28-30.

[92] M. Beller, C. Sztalryd, N. Southall, M. Bell, H. Jackle, D.S. Auld, B. Oliver, PLoS Biol. 6 (2008) e292.

[93] Y. Guo, T.C. Walther, M. Rao, N. Stuurman, G. Goshima, K. Terayama, J.S. Wong, R.D. Vale, P. Walter, R.V. Farese, Nature 453 (2008) 657-661.

[94] M. De Luca, N. Yi, D.B. Allison, J. Leips, D. Ruden, Obes. Res. 13 (2005) 1596-1605.

[95] M.H. Wang, L.G. Harshman, S.V. Nuzhdin, Obes. Res. 13 (2005) 1891-1897.

[96] W.W. Doane, J. Exp. Zool. 145 (1960) 1-21.

[97] T. Hader, S. Muller, M. Aguilera, K.G. Eulenberg, A. Steuernagel, T. Ciossek, R.P. Kuhnlein, L. Lemaire, R. Fritsch, C. Dohrmann, I.R. Vetter, H. Jackle, W.W. Doane, G. Bronner, EMBO Rep. 4 (2003) 511-516.

[98] J.M. Suh, D. Zeve, R. McKay, J. Seo, Z. Salo, R. Li, M. Wang, J.M. Graff, Cell. Metab. 6 (2007) 195-207.

[99] C.Q. Lai, L.D. Parnell, D.K. Arnett, B. Garcia-Bailo, M.Y. Tsai, E.K. Kabagambe, R.J. Straka, M.A. Province, P. An, I.B. Borecki, K.L. Tucker, J.M. Ordovas, Obesity (Silver Spring) 17 (2009) 593-600.

[100] X. Huang, K. Suyama, J. Buchanan, A.J. Zhu, M.P. Scott, Development 132 (2005) 5115-5124.

[101] S.E. Phillips, E.A. Woodruff, P. Liang, M. Patten, K. Broadie, J. Neurosci. 28 (2008) 6569-6582.

[102] J. Zheng, R. Mutcherson, S. Helfand, Aging Cell 4 (2005) 209-216.

[103] J. Zheng, S.W. Edelman, G. Tharmarajah, D.W. Walker, S.D. Pletcher, L. Seroude, Proc. Natl. Acad. Sci. U. S. A. 102 (2005) 12083-12088.

[104] S.N. Radyuk, K. Michalak, V.I. Klichko, J. Benes, I. Rebrin, R.S. Sohal, W.C. Orr, Biochem. J. 419 (2009) 437-445.

[105] I. Martin, M.A. Jones, D. Rhodenizer, J. Zheng, J.M. Warrick, L. Seroude, M. Grotewiel, Free Radic. Biol. Med. (2009).

[106] D.H. Han, L.A. Nolte, J.S. Ju, T. Coleman, J.O. Holloszy, C.F. Semenkovich, Am. J. Physiol. Endocrinol. Metab. 286 (2004) E347-E353.

[107] R. Minnaard, P. Schrauwen, G. Schaart, M.K. Hesselink, FEBS Lett. 580 (2006) 5172-5176.

[108] J. Hoeks, M.K. Hesselink, P. Schrauwen, Exp. Gerontol. 41 (2006) 658-662.

[109] P. Schrauwen, M.K. Hesselink, Diabetes 53 (2004) 1412-1417.

[110] J.W. Joseph, V. Koshkin, M.C. Saleh, W.I. Sivitz, C.Y. Zhang, B.B. Lowell, C.B. Chan, M.B. Wheeler, J. Biol. Chem. 279 (2004) 51049-51056.

[111] P. Hanak, P. Jezek, FEBS Lett. 495 (2001) 137-141.

[112] Y.W. Fridell, A. Sanchez-Blanco, B.A. Silvia, S.L. Helfand, J. Bioenerg. Biomembr. 36 (2004) 219-228.
[113] Y.W. Fridell, A. Sanchez-Blanco, B.A. Silvia, S.L. Helfand, Cell Metab. 1 (2005) 145-152.

[114] D.M. Humphrey, J.M. Toivonen, M. Giannakou, L. Partridge, M.D. Brand, Exp. Gerontol. 44 (2009) 316-327.

[115] A. Peter, C. Weigert, H. Staiger, K. Rittig, A. Cegan, P. Lutz, F. Machicao, H.U. Häring, E. Schleicher, Am. J. Physiol. Endocrinol. Metab. 295 (2008) E339-349.

[116] Z.Z. Li, M. Berk, T.M. McIntyre, A.E. Feldstein, J. Biol. Chem. 284 (2009) 5637-5644

[117] Y. Wei, D. Wang, M.J. Pagliassotti, Mol. Cell. Biochem. 303 (2007) 105-113.

[118] J.M. Ntambi, M. Miyazaki, J.P. Stoehr, H. Lan, C.M. Kendziorski, B.S. Yandell, Y Song, P. Cohen, J.M. Friedman, A.D. Attie, Proc. Natl. Acad. Sci. U. S. A. 99 (2002) $11482-11486$.

[119] M. Ueyama, T. Chertemps, C. Labeur, C. Wicker-Thomas, Insect Biochem. Mol Biol. 35 (2005) 911-920.

[120] L.M. Obeid, C.M. Linardic, L.A. Karolak, Y.A. Hannun, Science 259 (1993) 1769-1771.

[121] D. Dyntar, M. Eppenberger-Eberhardt, K. Maedler, M. Pruschy, H.M. Eppenberger, G.A. Spinas, M.Y. Donath, Diabetes 50 (2001) 2105-2113.

[122] T.S. Park, Y. Hu, H.L. Noh, K. Drosatos, K. Okajima, J. Buchanan, J. Tuinei, S. Homma, X.C. Jiang, E.D. Abel, I.J. Goldberg, J. Lipid Res. 49 (2008) 2101-2112.

[123] Y.T. Zhou, P. Grayburn, A. Karim, M. Shimabukuro, M. Higa, D. Baetens, L. Orci, R.H. Unger, Proc. Natl. Acad. Sci. U. S. A. 97 (2000) 1784-1789.

[124] K. Maedler, J. Oberholzer, P. Bucher, G.A. Spinas, M.Y. Donath, Diabetes 52 (2003) 726-733.

[125] M. Shimabukuro, Y.T. Zhou, M. Levi, R.H. Unger, Proc. Natl. Acad. Sci. U. S. A. 95 (1998) 2498-2502.

[126] M. Shimabukuro, M. Ohneda, Y.H. Lee, R.H. Unger, J. Clin. Invest. 100 (1997) 290-295.

[127] P.G. Ribaux, P.B. Iynedjian, Biochem. J. 376 (2003) 697-705.

[128] T. Adachi-Yamada, T. Gotoh, I. Sugimura, M. Tateno, Y. Nishida, T. Onuki, H. Date, Mol. Cell. Biol. 19 (1999) 7276-7286.

[129] A.D. Renault, M. Starz-Gaiano, R. Lehmann, Mech. Dev. 119 (Suppl. 1) (2002) S293-S301.

[130] A. Kohyama-Koganeya, T. Sasamura, E. Oshima, E. Suzuki, S. Nishihara, R. Ueda, Y Hirabayashi, J. Biol. Chem. 279 (2004) 35995-36002.

[131] D.R. Herr, H. Fyrst, V. Phan, K. Heinecke, R. Georges, G.L. Harris, J.D. Saba, Development 130 (2003) 2443-2453.

[132] V.H. Phan, D.R. Herr, D. Panton, H. Fyrst, J.D. Saba, G.L. Harris, Dev. Biol. 309 (2007) 329-341.

[133] U. Acharya, S. Patel, E. Koundakjian, K. Nagashima, X. Han, J.K. Acharya, Science 299 (2003) 1740-1743.

[134] E. Karaskov, C. Scott, L. Zhang, T. Teodoro, M. Ravazzola, A. Volchuk Endocrinology 147 (2006) 3398-3407.

[135] N.M. Borradaile, X. Han, J.D. Harp, S.E. Gale, D.S. Ory, J.E. Schaffer, J. Lipid Res. 47 (2006) 2726-2737.

[136] Y. Xie, J. Luo, S. Kennedy, N.O. Davidson, J. Biol. Chem. 282 (2007) 33043-33051

[137] C.S. Mendes, C. Levet, G. Chatelain, P. Dourlen, A. Fouillet, M.L. Dichtel-Danjoy, A. Gambis, H.D. Ryoo, H. Steller, B. Mollereau, EMBO J. 28 (2009) 1296-1307.

[138] H.D. Ryoo, P.M. Domingos, M.J. Kang, H. Steller, EMBO J. 26 (2007) 242-252.

[139] V.I. Rasheva, P.M. Domingos, Apoptosis 14 (2009) 996-1007.

[140] J. Borg, C. Klint, N. Wierup, K. Ström, S. Larsson, F. Sundler, R. Lupi, P. Marchetti, G. Xu, A.R. Kimmel, C. Londos, C. Holm, Endocrinology 150 (2009) 3049-3057.

[141] A.R. Kimmel, D.L. Brasaemle, M. McAndrews-Hill, C. Sztalryd, C. Londos, J. Lipid Res. (2009) Electronic publication ahead of print, doi:10.1194/jlr.R000034

[142] P.E. Bickel, J.T. Tansey, M.A. Welte, Biochim. Biophys. Acta 1791 (2009) 419-440

[143] D.L. Brasaemle, J. Lipid Res. 48 (2007) 2547-2559.

[144] C. Londos, C. Sztalryd, J.T. Tansey, A.R. Kimmel, Biochimie 87 (2005) 45-49.

[145] E.L. Arrese, L. Rivera, M. Hamada, S. Mirza, S.D. Hartson, S. Weintraub, J.L. Soulages, Arch. Biochem. Biophys. 473 (2008) 42-47.

[146] S. Grönke, M. Beller, S. Fellert, H. Ramakrishnan, H. Jäckle, R. Kühnlein, Curr. Biol 13 (2003) 603-606.

[147] L. Teixeira, C. Rabouille, P. Rorth, A. Ephrussi, N.F. Vanzo, Mech. Dev. 120 (2003) 1071-1081.

[148] J.D. Fauny, J. Silber, A. Zider, Dev. Dyn. 232 (2005) 725-732.

[149] J. Bai, R. Binari, J.Q. Ni, M. Vijayakanthan, H.S. Li, N. Perrimon, Development 135 (2008) 1439-1449.

[150] K. Köhler, E. Brunner, X.M. Guan, K. Boucke, U.F. Greber, S. Mohanty, J.M. Barth M.R. Wenk, E. Hafen, Autophagy (2009) 5.

[151] M. Mühlig-Versen, A.B. da Cruz, J.A. Tschäpe, M. Moser, R. Büttner, K.Z Athenstaedt, P. Glynn, D. Kretzschmar, J. Neurosci. 25 (2005) 2865-2873.

[152] P. Mourikis, G.D. Hurlbut, S. Artavanis-Tsakonas, Proc. Natl. Acad. Sci. U. S. A. 103 (2006) 1307-1312.

[153] M.L. Fluegel, T.J. Parker, L.J. Pallanck, Genetics 172 (2006) 185-196.

[154] S.P. Voght, M.L. Fluegel, L.A. Andrews, L.J. Pallanck, Cell. Metab. 5 (2007) 195-205.

[155] M. Tatar, A. Kopelman, D. Epstein, M.P. Tu, C.M. Yin, R.S. Garofalo, Science 292 (2001) 107-110.

[156] R. Böhni, J. Riesgo-Escovar, S. Oldham, W. Brogiolo, H. Stocker, B.F. Andruss, K. Beckingham, E. Hafen, Cell 97 (1999) 865-875.

[157] C. Werz, K. Köhler, E. Hafen, H. Stocker, PLoS Genet. 5 (2009) e1000596.

[158] N. Vereshchagina, M.C. Ramel, E. Bitoun, C. Wilson, J. Cell Sci. (2008).

[159] A.A. Teleman, Y.W. Chen, S. Cohen, Dev. Cell 9 (2005) 271-281.

[160] A.A. Teleman, Y.W. Chen, S. Cohen, Genes Dev. 19 (2005) 1844-1848.

[161] A.A. Teleman, S. Maitra, S. Cohen, Genes Dev. 20 (2006) 417-422.

[162] J.H. Reiling, K.T. Doepfner, E. Hafen, H. Stocker, Curr. Biol. 15 (2005) 24-30.

[163] J. Hull-Thompson, J. Muffat, D. Sanchez, D.W. Walker, S. Benzer, M.D. Ganfornina, H. Jasper, PLoS Genet. 5 (2009) e1000460. 
[164] A. Kohyama-Koganeya, Y.B. Kim, M. Miura, Y. Hirabayashi, Proc. Natl. Acad. Sci. U. S. A. (2008).

[165] A. Sánchez-Blanco, Y.W. Fridell, S. Helfand, Genetics 172 (2006) 1699-1710.

[166] K.T. Min, S. Benzer, Science 284 (1999) 1985-1988.

[167] Z. Pei, N.A. Oey, M.M. Zuidervaart, Z. Jia, Y. Li, S.J. Steinberg, K.D. Smith, P.A Watkins, J. Biol. Chem. 278 (2003) 47070-47078.

[168] Y. Zhang, D. Chen, Z.Y. Wang, Hum. Mol. Genet. 18 (2009) 3894-3905.

[169] P. Xu, S.Y. Vernooy, M. Guo, B.A. Hay, Curr. Biol. 13 (2003) 790-795.
[170] T. Okamura, H. Shimizu, T. Nagao, R. Ueda, S. Ishii, Mol. Biol. Cell 18 (2007) 1519-1529.

[171] N. Cobbe, K.M. Marshall, S.G. Rao, C.W. Chang, F. Di Cara, E. Duca, S. Vass, A. Kassan, M.M. Heck, J. Cell Sci. 122 (2009) 3414-3423.

[172] J.M. Suh, X. Gao, J. McKay, R. McKay, Z. Salo, J.M. Graff, Cell Metab. 3 (2006) 25-34.

[173] A. Callejo, J.a.M. Culi, I. Guerrero, Proc. Natl. Acad. Sci. U. S. A. 105 (2008) 912-917.

[174] M. Gazi, B.V. Shyamala, K.M. Bhat, Dev. Biol. 334 (2009) 311-323. 